\title{
한국의 대 중미 개발협력 현황과 과제
}

\section{목차}

I. 서론

II. 한국 $\mathrm{ODA}$ 의 과제와 $\mathrm{DAC}$ 가입

III. 한국의 중미 ODA 현황

IV. 한국 중미 ODA 지원의 과제

V. 나오면서

주제어: 공적개발원조(ODA), 국제개발협력, 중미, 과테말라, 국별지원전략

\section{I. 서 론}

1991년 이후 한국의 중미 ODA는 규모면에서 꾸준한 증가세를 보였다. 그럼에도 불구하고 중미지 역 지원 비율은 한국 $\mathrm{ODA}$ 의 $10 \%$ 내외에 머물러 있다. 이는 중미지역이 한국의 최우선 관심지역이 아니기 때문이기도 하고, 중미가 아프리카와 아시아와 같이 절대빈곤층이 많은 지역도 아니기 때문 이다. 중미 국가들은 최빈국에서는 벗어났지만 새천년개발목표(MDGs)의 항목별로 살펴보면 여전히 개선되어야할 사회 · 경제적 지표들을 보이고 있다. 전체적으로 소득불균형이 심하며, 계층간 격차, 인종적 격차, 도 - 농 간의 격차가 심각하다. 초등교육이 보편적으로 실시되어 문자해득율은 높지만 상급학교 진학률이나 직업교육과 같은 부분은 여전히 열악한 상태이다. 반면에 여성 권리 보장 및 양 성평등은 제도적인 측면에서는 잘 마련되어 있다. 그러나 현실적인 측면에서 보면 가부장적인 전통 이 남아있어 여성의 차별이 여전하고, 가정폭력과 성폭력, 직장에서의 폭력에 노출되어 있다. 이런 환경으로 인해 여성의 모성보건의 증진이 필요한데, 출산과정에서 사망하는 여성의 비율이 여전히 높다. 이와 같이 중미 국가들은 중소득국가들이 경험하고 있는 내용들을 공통적으로 겪고 있다. 그 동안 한국을 비롯한 많은 공여국들이 ODA를 지원했지만 중미국가들은 여전히 열악한 사회 - 경제적 환경에 노출되어 있다. 이런 이유로 $\mathrm{ODA}$ 의 효과성에 대한 논의들이 끊임없이 제기된다. 
본고 2장에서는 한국 $\mathrm{ODA}$ 의 현황과 $\mathrm{DAC}$ 가입에 따른 $\mathrm{ODA}$ 정책과제에 대해 분석한다. 한국은 1987년 대외경제협력기금(EDCF)을 조성하여 유상원조를 실시하고, 1991년 한국 국제개발협력단이 출범하면서 무상원조를 실시했다. 그리고 2009년 $\mathrm{OECD} / \mathrm{DAC}$ 가입으로 공식적으로 공여국으로서의 지위를 확고히 했다. 이런 과정에서 한국 ODA가 안고 있는 문제가 무엇인지 분석한다. 3 장에서는 한 국의 중미 ODA 현황을 국가별로 분석한다. 지난 20 년간 한국은 과테말라를 중점협력대상국가로 선 정하여 중미 사회의 발전을 위해 공적원조를 지원했는데, 그 동안 제공한 $\mathrm{ODA}$ 의 규모와 내용에 어떤 특징적인 요소들이 있었는가를 분석한다. 4 장에서는 한국의 중미 ODA 정책과제를 살펴본다. 한국의 대중미 ODA에서 나타나는 문제점 중에서 효과적인 ODA 지원과 원조효과성을 높이기 위한 정책 과 제는 무엇인가를 살펴볼 것이다. 5 장에서는 결론으로 한국의 중미 개발협력의 정책적 제언을 해보고 자 한다.

\section{II. 한국 $\mathrm{ODA}$ 의 과제와 $\mathrm{DAC}$ 가입}

\section{1. 한국 ODA의 제도와 지원}

한국이 ODA를 실시한 것은 1963년 미국 국제개발협력청(US AID)의 연수생 초청에서 시작되었다. 그러나 당시의 원조는 미국의 원조가 거쳐 가는 역할에 머물렀다. 실질적인 원조는 1987 년에 대외경 제협력법을 제정 - 실시하면서 국제개발원조사업에 공식적으로 첫발을 내디뎠다. 이 법령은 대외협력기 금(Economic Development Cooperation Fund, $\mathrm{EDCF})$ 의 설립을 승인하여 재정경제부의 책임 하에 개발도상국에 유상원조를 공여하는 것을 내용으로 한다. 그리고 1991년에는 한국국제개발협력단(Korea International Cooperation Agency, KOICA)을 설립하여 개발도상국에 대한 무상원조를 담당하게 했다. $\mathrm{OECD/DAC}$ 회원 가입 과정에서 관련법 제정과 정책 정비를 권고 받아 2010년 1월 25일에 '국 제개발협력기본법'을 2010년 7월 21일에는 시행령을 제정했다. ${ }^{1)}$ 이에 따라 국제개발협력에 관한 정 책이 종합적 · 체계적으로 추진될 수 있도록 심의 · 조정하기 위해 국제개발협력위원회를 설치했다. 지난 23년간 한국의 원조 규모는 꾸준히 증가했지만 국제적인 규범들의 적용을 받지 않아 규모나 내 용 면에서 많은 부분이 부족했다. ODA 지원 규모와 제도적 한계성은 있었지만 꾸준히 발전해 왔다. 이런 과정을 시기별 특성에 따라 구분하면 1987년 이전까지의 주축국 기간, 1991 년까지의 제도 마련 기, 2009년까지의 확장기를 거쳤고, 이제 DAC 가입으로 성숙기를 맞이하고 있다고 할 수 있다. 이런 의미에서 $\mathrm{DAC}$ 가입은 한국 $\mathrm{ODA}$ 지원의 역사적 전환점이 된다.

이를 반영하듯 한국 정부는 $\mathrm{ODA}$ 의 효율적 운영을 위해 국제개발협력 기본법을 제정했다. 기본법

1) 김경덕, 김정승, 「OECD/DAC 가입에 따른 개발도상국 농업기술지원 전략」, (한국농촌경제연구원, 2010), p.10 
의 목적에 보면 "이 법은 국제개발협력에 관한 기본적인 사항을 규정하여 국제개발협력 정책의 적정 성과 집행의 효율성을 제고하고 국제개발협력의 정책 목표를 효율적으로 달성하게 함으로써 국제개 발협력을 통한 인류의 공동번영과 세계 평화의 증진에 기여함을 목적으로 한다.”고 규정하고 있다. ${ }^{2)}$ 이러한 기본 목적은 갈퉁(Johan Galtung)의 적극적 평화론에 근거하고 있는 것으로 기존의 정치적 · 경제적 수단으로 활용하고 있던 수준과는 다른 차별성을 보인다. '갈퉁'의 적극적 평화론은 개발 또 는 발전을 넘어 평화, 특히 '적극적 평화(Positive Peace)'라는 보다 폭 넓은 관점에서 ODA에 접근해 야 할 뿐만 아니라 기존의 공여국 중심의 ODA 패러다임을 수원국의 요구를 반영하는 패러다임으로 전환하는 것을 포함한다. ${ }^{3)}$ 그럼에도 불구하고 현실적인 측면에서 적극적인 평화의 개념을 적용하고 있다고 보기 어렵다. 그것은 외교통상부가 밝히고 있는 것처럼 국제사회의 빈곤감소와 지속가능한 발전에 대한 기여로 규정하고 있기 때문이다. 포괄적인 의미에서 보면 적극적인 평화의 범위에 포함 될 수 있다는 것을 부정하기 어렵지만, ODA가 제공되는 국가와 사업 영역을 살펴보면 소극적 평화론 적인 입장에 머물러 있다. 이와 같이 철학적 - 개념적 문제와 현실적 · 경제적 문제가 부딪히고 있는 것이 한국 $\mathrm{ODA}$ 의 가장 큰 문제점이라 할 수 있다. 오랫동안 $\mathrm{ODA}$ 수원국으로서 경제발전이 최우선 과제였고 이를 뒷받침하기 위한 자원과 시장 진출이 매우 중요했던 한국의 역사적 경험이 그대로 반 영되고 있기 때문이다. 따라서 $\mathrm{ODA}$ 의 공공성이 상대적으로 취약한 것이 현실이다. 이런 문제는 기본 법에 기초한 제도적 개선 작업을 통해서 일부 보완될 수 있다.

한국의 경험이라는 측면에서 보면 경제발전의 경험은 같은 길을 가고자 하는 개도국들에게 가장 중요한 정신적 원조를 하고 있다. 대부분의 선진 공여국들도 자신들이 강점을 지니고 있는 인권과 거 버넌스 개선을 위해 많은 재원을 활용하고 있는데 ${ }^{4}$, 한국의 입장에서는 정치발전 보다는 경제발전을 중심으로 $\mathrm{ODA}$ 재원을 집중할 필요가 있다. 또한 한국 $\mathrm{ODA}$ 가 강조하는 빈곤 감소는 전지구적 의제 로서 당연히 수행해야 하는 과제이기도 하다. 사실 $\mathrm{OECD} / \mathrm{DAC}$ 가입은 여러 가지 의미를 지니는데 선진국으로서 지위가 명확해진다는 것을 의미한다. 따라서 국제사회가 공조하고 있는 국제적 이슈와 아젠다를 선도적으로 이끌어야 하는 의무를 동시에 지게 된다. 이런 측면에서 빈곤 감소는 한국의 적 절한 선택이 될 수 있다. 그렇지만 빈곤감소를 위한 지원과 운영 방식이 지극히 한국적이라는데 문제 가 있다. 각 국가마다 자국의 문화에 맞는 접근 방법과 정책이 있음에도 불구하고 한국인들의 사고방 식을 통해 해당 지역을 급격하게 변화시키려 한다는 것이다.

2) 외교통상부, 『국제개발협력기본법』, (외교통상부, 2010.07)

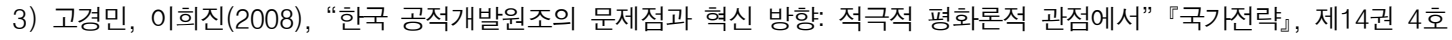
(2008), pp. 68-70.

4) 김영철, 구경모, 김유경, 박종욱, 「한 · 중미 개발협력방안 연구」, (대외경제정책연구원, 2010), pp.89-97. 


\section{2. $\mathrm{DAC}$ 가입에 따른 $\mathrm{ODA}$ 정책의 과제}

$\mathrm{OECD} / \mathrm{DAC}$ 가입에 따라 우리나라는 $\mathrm{ODA}$ 원조 공여조건에 대한 권고, 최빈국에 대한 비구속성 권 고 등 회원국으로서의 의무사항을 준수해야 한다. 우선 ODA 규모를 회원국들의 평균 수준으로 증액 해야 한다. 이에 따라 한국은 회원국 평균에는 미치지 못하지만 2015년까지 ODA 규모를 GNI 대비 $0.25 \%$ 인 약 30 억 달러로 증액하기로 하였고, 유엔이 정하고 있는 새천년개발목표(MDGs)를 추진해 야 하는 의무를 지니고 있고, 최빈국에 대한 증여율과 비구속성 원조 비중을 만족시켜야 한다. 이미 선진국들은 평균 $95 \%$ 이상이 비구속성 원조이나 한국은 $5 \%$ 정도만 비구속성 원조이다. 이런 규범적 문제와 더불어 원조 효과성을 높여야 하는 과제도 안고 있다. ${ }^{5)}$

첫째, ODA 지원 규모 확대에 대한 정부의 스케줄을 살펴보면 2015년까지 GNI 대비 0.25\%까지 증 액해야 하는 문제를 안고 있다. 사실 우리나라의 경제규모에 비해서 ODA 지원 규모는 매우 낮은 수 준에 있다. $\mathrm{DAC}$ 회원국의 전체 평균 비율이 $0.32 \%$ 인 것에 비하면 턱없이 부족하다. 1970 년 $\mathrm{UN}$ 은 70 년대 중반까지 GNI대비 $0.7 \%$ 까지 $\mathrm{ODA}$ 를 확대하는데 합의했으나 그 목표에 도달하지 못했다. 2005년 유럽연합의 15 개 회원국이 2015년까지 이 목표를 달성하는 데 합의했다. 우리나라도 2009년 -2010년 기간 호주, 벨기에, 캐나다, 일본, 포르투갈, 영국과 함께 가장 많이 증액된 국가이기는 하 지만 여전히 매우 낮은 수준에 머물러 있다. 2010년 기준으로 GNI 대비 가장 많이 지원한 국가는 노 르웨이로 GNI대비 $1.1 \%$ 를 지원했고, 그 뒤를 이어 룩셈부르크가 $1.09 \%$, 스웨덴이 $0.95 \%$, 덴마크가 $0.9 \%$ 를 지원하고 있다. 한국은 $0.12 \%$ 를 지원해 24 개 회원국 중에 꼴찌를 차지했다. ${ }^{6)}$

우리와 비슷한 그리스와 포르투갈이 각각 $0.17 \%$ 와 $0.29 \%$ 를 지원하고 있는 것과 비교하면 근접하 고 있지만 여전히 차이를 보이고 있다. 지원 규모에서는 미국, 영국, 독일, 프랑스, 일본 순이었다. 미국이 아이티 지진에 대한 구호 원조를 확대하면서 영국의 거의 두 배에 가깝게 지원했다. 이들 국 가들의 수준으로 지원한다는 것은 한국의 입장에서는 어렵겠지만, DAC 가입으로 약정한 2015년까지 GNI 대비 $0.25 \%$ 까지 확대해야 한다.

둘째, 한국은 새천년 개발목표 달성을 위해 빈곤퇴치와 관련된 문제에서 적극적인 자세를 취해야 하며 특히, 빈곤 퇴치 문제 대한 기술적인 접근을 필요로 하게 되었다. 새천년 개발목표는 2000년 9 월 UN에서 개최된 새천년 정상회의에서 채택된 빈곤퇴치를 위한 전 세계적인 약속으로 2015년까지 절대빈곤과 기아퇴치, 보편적 초등교육의 달성, 양성평등과 여성 능력의 고양, 유아사망률 감소, 산 모건강 증진, HIV/AIDS, 말라리아 및 기타 질병퇴치, 지속가능한 환경 보장, 개발을 위한 국제 파트 너십 구축 등 8가지 목표를 달성하는 것이다. 한국은 각 영역에서 지원을 확대하고 있는데, 특히, 의 료 보건 분야에서 좋은 성과를 거두고 있다. 한국은 보건소 모자보건요원 배치, 산전산후 진찰과 분

5) DAC 가입과 한국 ODA의 정책과제에 대해서는 손혁상, "DAC가입의 의의와 정책과제", 국제개발협력학회 정기학술회 의 자료집, ${ }^{\circledR}$ 한국의 DAC 가입과 HLF 개최의 의미와 과제』, (국제개발협력학회, 2010). 참조.

6) OECD/DAC, "Development aid reaches an historic high in 2010" http://webnet.oecd.org/oda2010/(2011.05.12). 
만 시행, 기생충 - 결핵퇴치 등 질병 관리 인프라 구축, 예방 접촉 사업 및 전염병 관리 등을 공유할 수 있는 보건 의료분야를 확대할 필요가 있다. 물론 절대빈곤 감소와 기아퇴치 지원도 확대해야 한 다. 절대빈곤과 기아퇴치를 포함한 분야에서 한국의 경험을 바탕으로 지원을 확대한다면 원조 효과 성을 높일 수 있을 것으로 기대된다. 새천년개발목표는 유상원조를 통해서도 가능하지만 많은 부분 이 무상원조로 지원된다. 무상원조가 공여국의 재원으로 이루어지는 사업이기 때문에 국내 기업의 진출 수단으로 활용되어야 한다고 보는 현실주의자들의 주장으로부터 좀 더 자유로워야 할 필요가 있다. 7) 새천년개발목표는 이러한 경제적 관점에서의 활용도보다는 인류애적인 관점에서 접근해야 한다. 따라서 대립적 관점을 지닌 집단들간의 다양한 주장들을 수렴하는 과정이 필요하다.

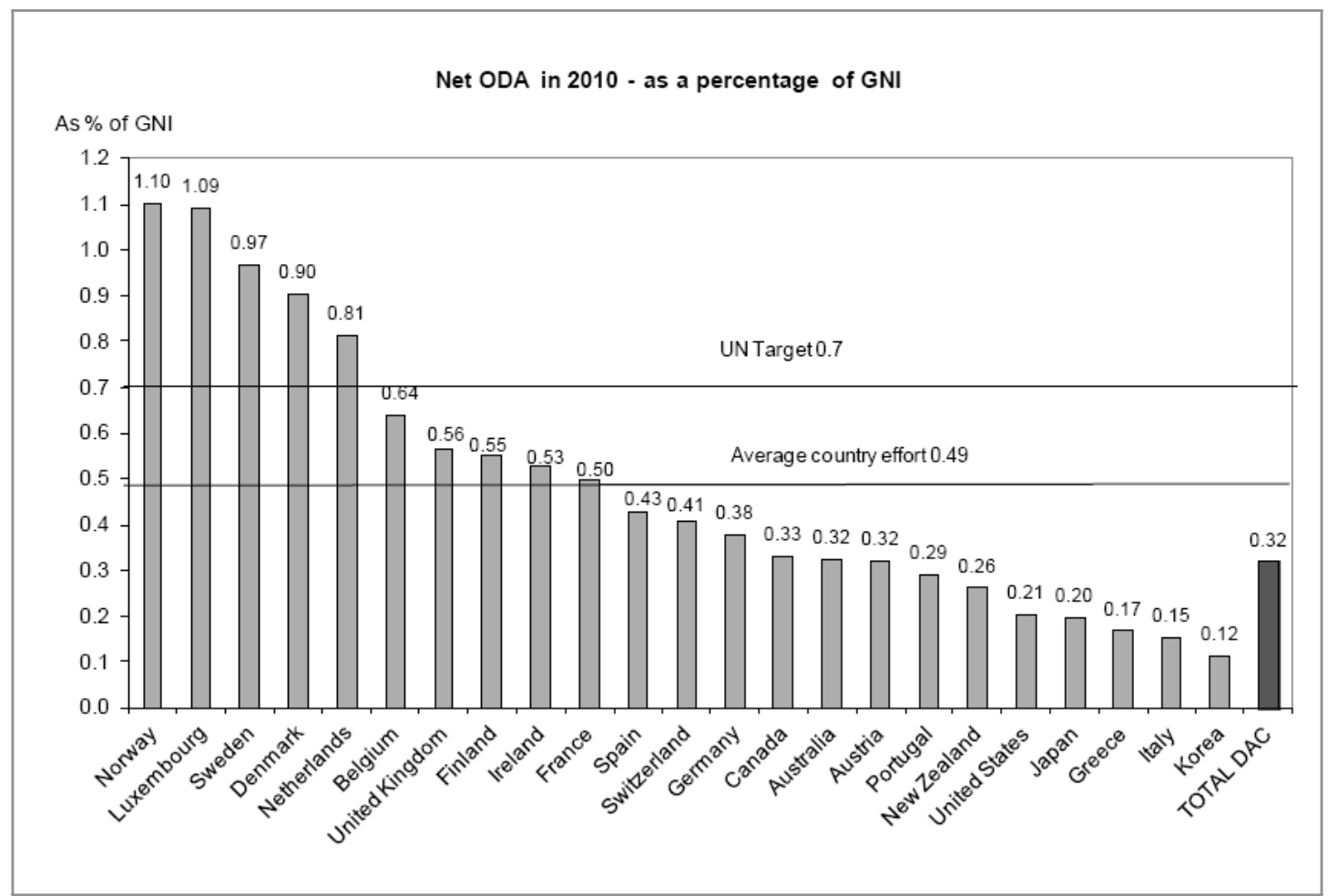

자료: OECD 2011년 4월

셋째, 최빈국에 대한 증여율과 비구속성 원조 비중을 만족시켜야 하는 문제를 안고 있다. 한국의 원조는 주로 구속성 원조가 대부분을 차지하고 있으며 약 $5 \%$ 만이 비구속성 원조였다. 구속성 원조는 협력국이 조달하는 수입물자 · 용역의 조달처를 공여국 또는 일부 소수국가로 한정하는 원조관행을 의미하며, 원조 공여국이 미리 차관의 용도와 차관에 의한 재화, 용역의 구매 조건을 원조 공여국을 비롯한 한정된 수의 국가들로 제한하는 방식이다. 이 방식에 따르면 공여국이 협력국의 ODA 집행에

7) 고경민, 김순임, 홍진혁, “공적개발원조(ODA)와 국인: 한국 ODA정책의 발전을 위한 함의", 『한국과 국제정치』, 제26권 제 3호, (경남대학교, 극동문제연구소, 2010). 95-128) 참고. 
직 - 간접적으로 참여할 수 있어 공여국의 자본이 기업을 통해 회수되는 효과와 공여국 기업이 협력 국에 진출할 수 있는 토대를 마련해 줄 수 있기 때문에 국익을 강조하는 현실주의자들이 유지하고자 하는 원조이다. ${ }^{8)}$ 그 동안 선진 공여국들은 이런 구속성 원조를 통해 협력국의 시장진출과 자원 확보 를 해왔던 것이 사실이다. 이런 측면에서 후발 공여국들은 선진 공여국들이 누리던 기득권을 버려야 한다는 측면에서 선진국의 '사다리 걷어차기'라는 비판을 받기도 한다. 협력국의 입장에서 보면 구속 성 원조는 공여국의 진입을 허용하는 결과를 초래한다는 측면에서 부정적이다. 대신에 비구속성 원 조는 조달 부분에 대한 어떤 제한을 가하지 않는 것으로서 공여국이 원조를 제공하여 진행하는 프로 젝트 사업에 참여할 수 있는 기업을 제한하지 않음으로써 자유경쟁이 가능하도록 한 것이다. 그렇다 고 하더라도 프로젝트 사업에 협력국의 기업이 주도적으로 참여하기는 어려운 부분이 있다. 원조를 받는 부분은 협력국이 인프라나 기술적 수준이 낮기 때문에 개선을 위해 추진되는 사업이기 때문이 다. 이런 단점에도 불구하고 $\mathrm{OECD} / \mathrm{DAC}$ 회원국을 비롯한 많은 원조 공여국들이 비구속성 원조를 수 용하여 확대하고 있다. 한국과 같이 국가주도의 개발경제 발전을 이룩한 경험을 지닌 국가들은 국가 재원이 직접적으로 국익을 창출하는데 쓰여지기를 바란다는 측면에서 국민적인 공감대를 형성하는데 많은 논란이 있다. 그럼에도 불구하고 한국 정부가 2010년 12 월 국제개발협력 시행령을 통해 비구속성 비율을 15 년까지 유상협력분야는 $50 \%$ 까지, 무상협력분야는 $100 \%$ 를 달성키로 하였으며, 전체 ODA 의 $1 \%$ 도 안되는 해외긴급구호 규모를 15 년까지 DAC 회원국 평균수준인 $6 \%$ 까지 확대하기로 했다.

넷째, 원조효과성을 높여야 한다. 사실 원조 효과성에 대한 논의는 원조가 협력국의 발전에 효과 가 있다는 주장, 협력국의 발전에 효과가 크지 않다는 주장, 그리고 특수한 상황에서 원조 효과가 나 타난다고 보는 3 가지로 경향으로 진행되었다. 원조 효과성은 파리선언과 아크라 행동계획을 통해 원 조 효과성 제고의 필요성과 구체적인 방안이 마련되었다. 한국도 이런 원조효과성을 담보하기 위한 제도적 노력과 함께 실질적인 평가 시스템을 마련해야 한다. 2005년 3월 $\mathrm{OECD}$ 산하 개발원조위원 회(Development Assistance Committee: DAC) 에서는 원조효과성 제고를 위한 회의가 있었다. 이 회의에서 90 여 개국과 OECD, World Bank, IMF 등 원조관련 다자기구 및 개발은행, NGO대표들이 파리에 모여 원조의 효율적 제공 및 운용방안을 논의하였다. 구체적으로는 UN '밀레니엄개발목 표'(MDGs)의 지난 5년간 추진결과 보고에 앞서 원조효율제고를 위한 구체적 방안 및 청사진이 수립 되고 파리선언(Paris Declaration)을 채택했다. 파리선언은 '원조의 질' 향상을 위하여 5 개 주요부문, 즉, 협력국 주도(Ownership), 일관된 조율(Alignment), 원조당사자간 조율(Harmonization), 결과 중심(Managing for Results), 상호책임(Mutual Accountability)을 설정하고, 이에 12 개의 구체적 측정 가능 지표(Indicators of Progress)를 작성, 각 지표의 목표 달성률을 모니터링 하도록 하였다. 이를 보완하기 위해 아크라 행동계획이 발표되었는데, 첫째, 개발에 대한 협력국의 오너십 강화, 둘

8) 구속성 원조의 문제점은 첫째, 공여국 중심의 원조로 인한 수원국의 주인의식을 저해하는 문제, 둘째, 비용효과성이 낮 다는 문제, 셋째, 원조의 투명성을 저하시키는 문제가 있다. 참여연대, 『한국 구속성 원조의 현황과 문제점, (참여연대 국제연대위원회 정책보고서, 2010) p. 5. 
째, 효과적, 포괄적 개발 파트너십 구축, 셋째, 개발성과 도출 및 책임강화 등을 핵 심사안으로 수원 국 주도의 원조효과 제고 방안을 모색하였다. ${ }^{9)}$ 아크라 행동계획은 130 여 개국(기관) 각료급 인사들 의 참여 하에 다양한 개발 파트너와의 포괄적 협의과정을 거쳐 채택함으로써 원조효과 제고를 위한 정치적 의지 강화의 계기가 되었으며, 2005년 파리선언에 비해 협력국 시스템의 활용, 원조 예측가 능성 개선 등 협력국 입장이 상당부분 반영된 진일보된 것으로 평가된다.

이러한 원조 효과성 강화에 따른 우리나라의 대응은 첫째, 원조 추진체제와 운용의 선진화가 필요 하다. 협력국 주도의 개발지원, 파트너십 강화를 통한 원조조화 증진, 협력국 역량 강화 지원 등 원 조 효과성 제고를 위해 국제원조규범을 준수하고 이를 모니터링, 평가할 수 있는 원조 추진 체제와 수행방식의 개선이 요구된다. 둘째, 포괄적 파트너십을 통한 원조조화가 필요하다. 다양한 개발협력 주체간 상호책임성, 정보공유 강화 등을 위해 포괄적 파트너십 활성화로 새로운 개발협력 모델 및 우 수사례를 적극 발전시켜 개발원조를 확대할 필요가 있다. 셋째, 시민사회의 개발역량 확충이 필요하 다. 우리나라의 성공 사례 및 노하우를 발전시켜 협력국의 국가개발전략, 사업정책 분야의 개발컨설 팅 확대 등 개발경험의 공유를 활성화하고 전통 공여국과 신흥 공여국간의 촉매제 역할을 강화할 필 요가 있다. ${ }^{10)}$

\section{III. 한국의 중미 ODA 현황}

\section{1. 한국 $\mathrm{ODA}$ 에서 중미지역의 현황}

중미지역은 지리적인 위치와 문화적인 측면에서 한국과는 거리가 있다. 특히 한국이 중요하게 생 각하는 자원 확보, 수출시장, 전략적인 측면에서 볼 때 그 중요성은 동남아 지역과 비교했을 때 높지 않다. 이런 면들은 한국이 제공하는 ODA에도 그대로 반영되고 있는데, 가장 많은 ODA가 제공되는 지역은 역시 동남아시아이다. 다음으로는 최근 유엔의 MDGs가 발표된 이후 빈곤퇴치를 위해 아프리 카 지역에 대한 ODA가 확대되고 있다. 중남미지역은 〈표 1〉에서 보는 바와 같이 2009년 기준으로 $12.6 \%$ 를 차지하고 있다. 중남미에 제공되는 $\mathrm{ODA}$ 의 많은 부분은 자원 확보를 위한 전략적인 고려가 필요한 국가들에게 집중되어 있고, 중미지역은 1 억 8 백만 달러로 $36 \%$ 를 차지한다. 전체적으로 중미 지역에 대한 ODA 규모를 확대할 필요가 있다는 것을 단적으로 보여준다. 다행히 2011년 현재 전체 $\mathrm{ODA}$ 의 비율에서는 크게 변화되지 않았지만 지원규모가 확대되었다.

중남미 전체지역에 대한 $\mathrm{ODA}$ 규모는 점진적으로 증가해 왔다. ${ }^{11) ~ 〈 ㅍ ㅛ 1 〉 ㅇ ㅔ ㅅ ㅓ ~ ㅂ ㅗ ㄴ ㅡ ㄴ ~ ㅂ ㅏ ㅇ ㅘ ~ ㄱ ㅏ ㅌ ㅇ ㅣ ~} 2010$

9) 권율, 정지선, "국제사회의 파리선언 이행 현황과 시사점", KIEP, 『오늘의 세계경제』, (대외경제정책연구원, 2008) 참조.

10) ODA Watch, (23호) "아크라 행동계획(AAA) 채택의 의의와 과제",

http://www.odawatch.net/?mid=articlesth\&page=20\&document_srl=2048(2011.05.12) 
년에 중남미지역에 대한 전체 비율이 $14.6 \%$ 로 증가했는데, 이것은 한국정부가 $\mathrm{OECD} / \mathrm{DAC}$ 가입이 확정되고 공적원조 지원의 방향을 '감사하는 대한민국-은혜를 갚을 줄 아는 국가'라는 슬로건 하에 한국전쟁 참전 국가인 콜롬비아에 대한 지원을 확대했기 때문이었다. 전체적으로 공적원조 규모가 증가되는 추세였지만 2007년을 기점으로 다소 감소하는 경향이 있었으나 DAC 가입으로 공적원조를 확대하고 있다. 반면 중미지역에 대한 ODA 규모는 오히려 증감현상을 보이기는 하지만 감소하는 경 향을 알 수 있다. 특히 2010년은 한국 ODA에서 중남미지역에 대한 지원이 확대되었음에도 불구하고 중미지역에 대한 지원이 감소하고 있다. 이는 중미지역의 사회 · 경제적 환경 개선에 기인한다기보다 는 한국 $\mathrm{ODA}$ 지원 전략의 변화에서 비롯되었다. 석유 가격 폭등을 비롯한 세계적인 자원전쟁이 확대 되면서 한국의 외교 전략은 리튬을 포함하는 히토류 확보로 전환하는 경향을 보였고 여기에 볼리비 아와 페루에 매장되어 있는 자원 확보를 위해 ODA가 활용되었다. ${ }^{12)}$ 이런 과정들은 자원 외교를 표 방했던 한국 정부의 적극적인 지원으로 추진되었다.

\section{〈표 1〉한국 ODA의 중미 지역 지원 비율}

\begin{tabular}{l|r|r|r|r|r}
\hline \multicolumn{1}{c|}{ 구분 } & 2006년 & 2007년 & 2008년 & 2009년 & 2010년 \\
\hline 전체 예산 & 193.5 & 270.2 & 275.2 & 279.3 & 375.5 \\
\hline 증가율 & $21.7 \%$ & $19.7 \%$ & $28.2 \%$ & $16.9 \%$ & $18.0 \%$ \\
\hline 중남미 전체 예산 & 14.0 & 35.6 & 32 & 30 & 37 \\
\hline 전체 대비 중남미 비율 & $7.2 \%$ & $13.2 \%$ & $11.6 \%$ & $12.6 \%$ & $14.6 \%$ \\
\hline 중미 지역 예산 & 5.5 & 10.9 & 9.3 & 10.8 & 9.2 \\
\hline 중남미 대비 중미 비율 & $39.3 \%$ & $30.6 \%$ & $29.1 \%$ & $36.0 \%$ & $24.9 \%$ \\
\hline
\end{tabular}

출처: 최원식, “한국의 대중미 개발협력 사례와 협력확대 방안” 한중남미협회, 『제14차 한 · 중남미 비즈니스 포럼』, (한중남미협회, 2010).

한국의 중미 ODA는 1991년 이후 지속적으로 확대되어 왔다. 중미지역은 DAC가 구분하고 있는 최 빈국, 저소득국은 없는 지역이며, 대부분이 중저소득국들이다. 벨리즈, 코스타리카와 파나마는 고중 소득국가로 점차적으로 ODA 규모가 축소되고 있는 국가이다. 〈표2〉에서 보는 바와 같이 2000년 $\mathrm{KOICA}$ 의 대중미 7 개국 개발협력 규모는 11 억 2 천 5 백만원에 불과했으나, 2008 년에는 85 억 2 천 5 백만 으로 8 배 이상 증가하였다. 지원규모로 살펴보면 과테말라가 134 억 5 천 6 백만원으로 가장 많은 부분 을 차지한다. 과테말라는 KOICA가 중미지역에서 유일한 중점협력대상국으로 선정한 국가이며 중미 지역에서 효율적으로 사업을 추진하기 위해 사무소를 설치하여 운영하고 있다. 다음으로는 엘살바도 르로 21 억7천 1 백만을 지원했다. 그 동안 중미지역에서는 코스타리카가 가장 적게 지원받았는데, 코

$11)$ 이현주, 『한국의 대 중남미 무상원조방안 연구』, (KOICA, 2008), p.104.

12) 중앙일보, "이상득, '자원외교' 특사로 중남미 방문", (중앙일보, 2010.01.18.) 
스타리카는 $\mathrm{DAC}$ 가 구분하는 고중소득 국가이기 때문에 지원규모가 크지 않다. 본 연구에서도 코스 타리카가 고중소득 국가로 분류되고, 한국이 $\mathrm{ODA}$ 를 점진적으로 축소하고 있는 국가이며, 성공적인 $\mathrm{ODA}$ 지원으로 성장을 이루고 있기 때문에 개별 국가 분석 대상에서는 포함시키지 않을 것이다.

〈표 2〉KOICA의 중미 7개국 개발협력 규모(2000년 2008년)

(단위: 백만원)

\begin{tabular}{c|r|r|r|r|r|r|r|r|r|r|r}
\hline 구분 & 2000년 & 2001년 & 2002년 & 2003년 & 2004년 & 2005년 & 2006년 & 2007년 & 2008년 & 2009년 & 합계 \\
\hline 과테말라 & 194 & 273 & 316 & 1,415 & 1,023 & 1,409 & 1,842 & 2,668 & 4,316 & 5,001 & 18,457 \\
\hline 온두라스 & 78 & 114 & 129 & 506 & 71 & 81 & 429 & 1,651 & 662 & 293 & 4,014 \\
\hline 엘살바도르 & 121 & 289 & 782 & 246 & 349 & 2,019 & 284 & 1,139 & 2,171 & 4,901 & 12,301 \\
\hline 니카라과 & 250 & 55 & 703 & 159 & 358 & 499 & 358 & 138 & 202 & 111 & 2,833 \\
\hline 파나마 & 144 & 39 & 629 & 312 & 367 & 502 & 342 & 1,793 & 1,044 & 718 & 5,890 \\
\hline 벨리즈 & 64 & 66 & 448 & 80 & 45 & 16 & 424 & 329 & 105 & 24 & 1,601 \\
\hline 코스타리카 & 274 & 272 & 484 & 431 & 450 & 330 & 536 & 1,294 & 25 & 155 & 4,251 \\
\hline 합계 & 1,125 & 1,108 & 3,491 & 3,149 & 2,663 & 4,856 & 4,215 & 9,012 & 8,525 & 11,203 & 49,347 \\
\hline
\end{tabular}

출처: KOICA 통계자료

그 동안 한국은 대외활동의 많은 부분을 경제성장을 위한 전략적으로 활용해 왔다. 자원이 부족한 한국의 입장에서는 당연한 선택이라고 할 수 있다. 또한 국내 시장이 협소한 한국으로서는 수출시장 이 반드시 필요했고 그 시장 개척을 위해 다양한 전략을 추진해 왔으며 KOICA의 무상지원과 수출입 은행의 $\mathrm{EDCF}$ 도 이런 측면에서 활용되어 왔다. $\mathrm{EDCF}$ 의 경우에는 유상원조이기 때문에 수출시장 혹 은 기업 진출을 위한 전략적 접근으로 제공하는 경우가 많았다. 특히 그 동안의 유상원조의 많은 부 분이 구속성 원조였다는 것이 이를 뒷받침한다. 때문에 현지에서는 한국도 다른 선진 공여국과 마찬 가지로 자국의 경제적 부를 수탈하는 국가로 비춰지기도 했다. 그러나 최근 유상원조 차관인 $\mathrm{EDCF}$ 의 규모를 점진적으로 축소하고 있고, 유상원조도 비구속성 원조 형태로 전환하고 있다.

\section{2. 중미 국가별 지원 현황}

\section{1) 과테말라}

과테말라에 대한 한국의 총 지원 규모는 다른 중미 국가에 비해 크고, ODA 제공 역사도 비교적 길 다. 한국은 1991년 KOICA가 설립되면서 본격적으로 ODA를 제공해왔는데 과테말라는 설립 원년부터 지속적으로 ODA가 제공되었다. 지원규모도 매년 증가하여 지금까지 20 억 1천1만불에 이른다. 또한 2006년에 2007-2009년 대외무상원조 중기전략에 따라 파라과이, 페루와 함께 중점협력대상국으로 
선정되면서 $\mathrm{ODA}$ 지원이 증가했다. 과테말라에는 한국이 집중적으로 지원해 온 ICT분야의 성과가 두 드러지게 나타났고, 이를 바탕으로 중미의 다른 국가들로 2차 혹은 남남협력을 통해 개발협력사업을 확대할 수 있었다. 이는 과테말라가 중미에서는 비교적 $\mathrm{ODA}$ 집행이 투명하고 행정적으로 이를 뒷받 침할 수 있는 시스템을 구축하고 있기 때문이다. 이러한 객관적인 조건 때문에 많은 선진 공여국들이 우선 협상대상국으로 선정하기도 한다. 이는 ODA가 원조 효과성의 측면에서 보면 과테말라가 긍정 적인 국가로 발전하고 있는 것이라 할 수 있지만, 다른 측면에서는 선진국의 ODA가 일국에 집중되는 단점으로 작용하기도 한다. 한국이 과테말라에 지원한 $\mathrm{ODA}$ 의 많은 부분이 ICT산업으로 편중되어 있 는데 이것은 한국이 강점을 지니고 있는 분야이기도 하고 과테말라가 지원을 원하는 방향이기도 하 다.

\section{〈표 3〉과테말라 지원 규모}

(단위: 만 달러)

\begin{tabular}{c|c|c|c|c|c|c|c|c|c|c|c}
\hline 연도 & 91-00년 & 2001년 & 2002년 & 2003년 & 2004년 & 2005년 & 2006년 & 2007년 & 2008년 & 2009년 & 계 \\
\hline 지원액 & 357 & 21 & 25 & 119 & 89 & 138 & 193 & 287 & 389 & 393 & 2,011 \\
\hline
\end{tabular}

출처: $\mathrm{KOICA}$ 통계 자료

사업형태별로 보면 프로젝트, 개발조사, 물자지원, 긴급구호, 국내초청연구, 전문가 파견, 봉사단 파견, 민간단체 지원 순으로 이루어져 있다. 초기 사업은 주로 아동복지원과 광물탐사사업으로 사업 영역이 매우 제한적이었다. 그러다가 2000년대에 진입하면서 ICT와 교육 등으로 사업 영역이 다소 특화되는 현상을 볼 수 있다. 한국 ODA의 가장 일반적인 지원 형태가 프로젝트형인데 과테말라의 경 우에도 역시 프로젝트형 사업이 많은 부분을 차지하고 있다. 우리나라 ODA사업은 대체로 2-5년을 사업기간으로 하는 장기 프로젝트는 소수에 그치고, 대부분 1 년이 안 되는 경우이며 특정 상업의 경 우에는 2 3개월의 단기사업 중심으로 이루어져왔다. 단기적 시각에서 이루어지는 원조사업 수요조 사는 수혜국의 요구 시 어느 정도 반영되기는 하지만 전반적인 개발의 목표, 주요정책과제, 투자우선 순위 등에 입각한 유망 사업을 발굴하는 데는 제한적일 수밖에 없다. 또한 프로젝트 사업은 협력국의 입장보다는 공여국의 입장에서 고려되어 추진되는 경우가 많다. 따라서 원조 효과성에서 좋은 결과 를 가져오기는 어려운 측면이 있다. 단기간에 이루어지기 때문에 공여국의 입장에서는 지원성과를 과시적으로 나타낼 수 있지만, 협력국의 발전에 도움이 되는가라는 측면에서 평가하기 어렵다는 것 이다. 이러한 문제를 해결하기 위해서는 프로그램 기반의 지원형태(PBA: Program Based Approach) 로 바꿀 필요가 있다. 
〈표 4〉과테말라 사업형태별/분야별 지원 현황

\begin{tabular}{|c|c|c|}
\hline 분야별 사업 형태 & 사업내용 (사업기간 / 지원규모) & 분야 \\
\hline \multirow{16}{*}{ 프로젝트(16건) } & 제 1 아동복지원 건립사업(1993-1995, 1998-1999/72만 달러) & 보건 \\
\hline & 제 2 아동복지원 건립사업(1997-1998, 2000/56만 달러) & 보건 \\
\hline & 제 3 아동복지원 건립사업(1997-1998, 2000/59만 달러) & 보건 \\
\hline & 외교부 e-Library 구축사업(2002-2003/38만 달러) & 공공행정 \\
\hline & 기술교육 훈련원 건립사업(2002-2004/117만 달러) & 교육 \\
\hline & 섬유기술훈련원 지원사업(2005-2006/88만 달러) & 교육 \\
\hline & 한-과테말라 ICT 교육센터 건립사업(2006-2008/262만 달러) & 교육 \\
\hline & 청소년직업훈련원 자동차정비훈련소 건립(2007-2008/57만 달러) & 교육 \\
\hline & 난민정착 지원 및 교육강화사업(2007-2009/182만 달러) & 교육 \\
\hline & 전자정부 행정민원 서비스 구현 웹 포털 시스템 구축(2008-2009/111만 달러) & 공공행정 \\
\hline & 모자보건환경 개선사업(2008-2009/278만 달러) & 보건 \\
\hline & 국세청 위험관리능력향상 및 데이터웨어하우스 구축사업(2009/6만 달러) & 공공행정 \\
\hline & 과테말라 모자보건 역량강화 사업(2010-2012) & 보건 \\
\hline & 소녀의 집 교육역량 강화사업(2010) & 교육 \\
\hline & 산후나 꼬찰시 교육 인프라 강화사업(2010-2011) & 교육 \\
\hline & 외교부 현대화사업(2010) & 교육 \\
\hline 개발조사(1건) & 광물탐사사업(1994-1996, 1998/59만 달러) & 공공행정 \\
\hline 물자지원 & 경찰차량, 휠체어, 컴퓨터 등 25건(171만 달러) & 산업에너지 \\
\hline 긴급구호 & 분유, 의약품 등 4건(45만 달러) & - \\
\hline 국내초청연수 & 376명(318만 달러) & - \\
\hline 전문가파견 & 채소재배, 광업, 직업훈련 등 분야 7명(10만 달러) & - \\
\hline 봉사단파견 & 10명(62만 달러) & - \\
\hline 민간단체 지원 & 2건(21만 달러) & - \\
\hline
\end{tabular}

출처: $\mathrm{KOICA}$ 통계 자료

물론 프로젝트형 사업 모두가 원조 효과성이 낮다고 평가하기는 어렵다. 일부 사업의 경우에는 협 력국의 적극적인 지원으로 계획했던 사업 규모보다도 횔씬 확대된 사업을 추진하는 경우도 있다. 정 보통신산업진흥원과 함께 추진한 '한-과테말라 ICT 교육센터 건립사업'이 대표적인 사례이다. 과테 말라 정부의 적극적인 지원으로 원래 계획했던 것보다 규모와 내용 면에서 확대되었다. 현재 5 층 규 모의 건물에 컴퓨터, 서버와 네트워크 설비를 갖추고 있으면 한국에서 파견된 컴퓨터 전문가들이 2 
개의 교육 과정을 운영하고 있다. 이 교육센터는 중미에서 최첨단 ICT 훈련 센터이며 과테말라 ICT 인력 개발능력 개선이 크게 이바지 하고 있다. ${ }^{13)}$ 한국이 과테말라에 제공한 ODA 중에서 공여국의 장점과 협력국의 요구 사항이 가장 잘 조화를 이룬 것이다.

\section{〈표 5〉2000년 2009년 과테말라 사업 분야별 현황}

(단위: 백만원)

\begin{tabular}{c|r|r|r|r|r|r|r|r|r|r|r}
\hline 구분 & 2000년 & 2001년 & 2002년 & 2003년 & 2004년 & 2005년 & 2006년 & 2007년 & 2008년 & 2009년 & 합계 \\
\hline 교육 & 26 & 9 & 17 & 739 & 635 & 731 & 268 & 122 & 660 & 207 & 3,414 \\
\hline 보건의료 & 0 & 57 & 44 & 47 & 59 & 6 & 0 & 0 & 964 & 2,673 & 3,850 \\
\hline 행정제도 & 162 & 139 & 125 & 59 & 148 & 153 & 367 & 644 & 356 & 260 & 2,413 \\
\hline 농어촌개발 & 0 & 4 & 24 & 16 & 27 & 26 & 0 & 703 & 1,046 & 535 & 2,381 \\
\hline 정보통신 & 0 & 24 & 81 & 518 & 143 & 171 & 1,205 & 1,137 & 1,107 & 1,066 & 5,452 \\
\hline 산업에너지 & 5 & 25 & 13 & 28 & 9 & 5 & 0 & 0 & 0 & 13 & 98 \\
\hline 환경 및 기타 & 0 & 11 & 8 & 5 & 0 & 0 & 0 & 60 & 139 & 138 & 361 \\
\hline 긴급구호 & 0 & 0 & 0 & 0 & 0 & 312 & 0 & 0 & 40 & 106 & 458 \\
\hline 합계 & 193 & 269 & 312 & 1,412 & 1,021 & 1,404 & 1,840 & 2,666 & 4,312 & 4,998 & 18,427 \\
\hline
\end{tabular}

출처: $\mathrm{KOICA}$ 대외무상원조 통계 재구성

사업분야별로 지원 규모를 살펴보면 〈표 5〉와 같다. 그 동안 정보통신분야에 대한 지원이 가장 많 은 부분을 차지하는데 2006년을 기점으로 그 규모가 확대된 것을 알 수 있다. 정보분야의 지원 확대 는 앞에서 언급한 ICT 교육센터 건립과 무관하지 않다. ICT 교육 센터 건립으로 정보통신분야의 인 력이 확충되면서 이 분야에 대한 지원도 확대되었는데, 전자정부 행정민원 서비스 구현 웹포탈 시스 템 구축과 국세청 위험관리능력 향상 및 데이터 웨어하우스 구축 사업 등에 대한 지원이 확대되었다. 2009년에는 보건의료 분야의 지원이 증가한 것을 알 수 있다. 최근 한국은 남미지역에서 모자보건 지원 사업을 벌려 좋은 성과를 거두었다. 이를 모델로 과테말라를 비롯한 중미지역으로 모자보건 지 원 사업을 확대하고 있는데 그 결과로 규모가 점진적으로 확대되고 있다. 2007-2009년 치말떼낭고 (Chimaltenango)주 모자보건 개선 사업을 시작으로 2010년에는 과테말라 모자보건 역량강화 사업 을 추진하면서 이 부분에 대한 지속적인 지원이 유지되고 있다.

13) 과테말라 ICT 교육 사업 평가는 주인중, 김상진, “과테말라기술교육훈련원 건립 사업 사후평가", 「국제개발협력」, 2008년 2호(한국국제협력단, 2008), 김준연, “한-중남미 IT 서비스 분야 협력 및 현지 시장 진출 방안”, 한중남미 협 회, 『제14차 한·중남미 비즈니스 포럼』, (한중남미협회, 2010), 최원식, “한국의 대중미 개발협력 사례와 협력확대 방안” 한중남미협회, 『제14차 한 · 중남미 비즈니스 포럼』, (한중남미협회, 2010) 참고 


\section{2) 니카라과}

니카라과는 지난 10 년간 통계를 살펴보면 2005년과 2006년에 원조가 증가했다가 다시 점차적으 로 줄어들고 있는 국가이다. 니카라과에 대한 공적원조 감소는 니카라과가 지니고 있는 정치적 위험 성과 무관하지 않는데, 정치 혼란으로 인해 공적원조가 지원될 수 없었다. 또한 공적 원조 관리시스 템이 허술하여 원조가 목적한 사업에 집행되지 않는 경우가 많아 정부차원에서 니카라과에 대한 지 원을 축소하고 있는 부분이 있다. 특히 민주 정부 수립과 거버넌스 문제가 발생하고 있는 국가로 우 리나라가 경험이 부족한 분야이기 때문에 지원을 확대할 수 없는 부분도 있었다. 정부의 거버넌스 문 제는 주로 북유럽의 원조국가들이 국가협력전략을 수립하여 지원하는 분야로 한국의 입장에서는 원 조 효과성을 얻기 어려운 부분이 있었다. 2009년까지 니카라과에 지원한 금액은 4억 8천6백만 달러 로 과테말라의 $1 / 4$ 수준에 머물러 있다. 과테말라가 중점 협력 대상국가로 선정되어 많은 지원을 받 은 것에 비하면 니카라과의 지원 규모는 이제 시작되는 단계라 할 수 있는데 오히려 지원 규모가 축 소되는 것을 알 수 있다. 공적원조는 개별 국가의 긴급 사안이 발생했을 경우에 급격히 증가하기도 하고 감소하기도 한다. 지난 2008년 11월 니카라과 부정 선거로 유혈 충돌이 발생했을 때 미국은 니 카라과의 MCA 프로그램의 중지를 선언했다. ${ }^{14)}$ 이와 같은 정변이 발생하면 ODA가 오용될 수 있는 위험성이 있으며, 설사 그렇지 않다고 하더라도 지원이 원활하게 이루어지지 않는 경우가 많다. 한국 도 공식적으로 $\mathrm{ODA}$ 지원을 중단한다고 선언하지는 않았지만 표에서 보는 바와 같이 2009년 지원규 모가 2008년의 절반 수준에 머물렀다. 같은 시기 선진 공여국들의 원조가 줄었지만 대신에 베네수엘 라와 쿠바의 원조가 증가했다. 특히 차베스 대통령은 니카라과에 대규모 원조를 약속하기도 했다.

\section{〈표 6〉니카라과 지원 규모}

(단위: 만 달러)

\begin{tabular}{c|c|c|c|c|c|c|c|c|c|c|c}
\hline 연도 & 91-00년 & 2001년 & 2002년 & 2003년 & 2004년 & 2005년 & 2006년 & 2007년 & 2008년 & 2009년 & 계 \\
\hline 지원액 & 253 & 4 & 56 & 13 & 31 & 49 & 37 & 15 & 18 & 9 & 486 \\
\hline
\end{tabular}

출처: KOICA 통계 자료

사업형태별로 보면 니카라과 프로젝트는 주로 교육과 직업훈련과 관련되어 있는데 이 분야는 한국 이 중미지역에서 강점을 지니고 있는 사업 영역이다. 그런데 니카라과에서는 직업훈련이 현장 취업 으로 이어지는 시스템을 보다 잘 구축해야 효과성을 높일 수 있을 것으로 조사됐다. 반면 자연재해가 빈번하게 발생하는 지역으로 물자지원과 국내초청연수가 많은 부분을 차지하고 있다. 사실 니카라과 는 한국이 강점을 지니고 있는 ICT 산업 전반이 매우 낙후되어 있다. 특히 니카라과의 경우에는 정부

14) MCA(Millenium Challenge Account)는 미국정부가 2002년에 개도국들의 경제성장과 빈곤감소를 위해 지원하기 위해 만든 프로그램으로 주로 최빈국들을 중심으로 지원하고 있는 프로그램이다.

"USA Profile" www.development-finance.org/en/component/.../634-usa-24-09-2009.html(2011.5.30) 
의 표준안 마련을 위한 노력이 미흡할 뿐 아니라 ICT에서도 우리가 강점을 지닌 IT 분야에 있어서 관 련 인프라가 지나치게 열악하여 진출과 개발 협력이 수행된다 하더라도 결과로서 드러나는 정도가 매우 미흡할 것으로 예측되기 때문이다.

〈표 7〉니카라과 사업형태별/분야별 지원 현황

\begin{tabular}{c|l|c}
\hline \multirow{2}{*}{ 사업 형태 } & \multicolumn{1}{|c|}{ 사업내용 (사업기간 / 지원규모) } & 분야 \\
\hline \multirow{2}{*}{ 프로젝트 } & 니카라과 벽지농촌 초등학교 교원주택 건립사업(1997-1999/115만 달러) & 교육 \\
\cline { 2 - 4 } & 니카라과 직업훈련센터 개선사업 (2002-2003/35만 달러) & 교육 \\
\cline { 2 - 4 } & 니카라과 국립농업기계화 훈련원 현대화 사업(2004-2005/36만 달러) & 농림수산 \\
\cline { 2 - 4 } & 니카라과 외교부지원체제 구축사업(2005-2006/58만 달러) & 공공행정 \\
\hline 물자지원 & 21건(136만 달러) & - \\
\hline 긴급구호 & 4건(39만 달러) & - \\
\hline 국내초청연수 & 92명(66만 달러) & - \\
\hline 전문가 & 3명(2만 달러) & - \\
\hline
\end{tabular}

출처: $\mathrm{KOICA}$ 통계 자료

니카라과에 대한 사업분야별 지원 현황을 살펴보면 지속적으로 지원한 분야가 거의 없는 것을 알 수 있다. 초기에는 행정제도와 교육 부분에 대한 지원이 많았으나 이마저도 2006년을 기점으로 지원 이 중단된 경우가 많다. 대신 2005년 이후 정보통신 분야에 대한 지원이 확대되었으나 규모가 점차 줄어들었다. 이는 2006년에 오르테가가 집권 이후 지속된 정치 불안과 무관하지 않다. 집권에 성공 한 오르테가가 보건, 교육, 문맹퇴치와 빈곤 감소 프로그램을 실시하기 위해 시민권력 위원회 설치해 운영했지만 이 기관이 오히려 대외원조의 직접적인 지원과 관리를 어렵게 했다. 이런 정치적인 사건 으로 인해 니카라과에 대한 선진 공여국들의 원조는 지속적으로 감소했다. 니카라과 경제의 상당부 분이 대외원조에 의존하고 있었던 점을 고려한다면 국내 경제 상황이 위기에 직면했다는 것을 알 수 있다.

\section{〈표 8〉2000년 2009년 니카라과 사업분야별 현황}

(단위: 백만원)

\begin{tabular}{|c|c|c|c|c|c|c|c|c|c|c|c|}
\hline 구분 & 2000년 & 2001년 & 2002년 & 2003년 & 2004년 & 2005년 & 2006년 & 2007년 & 2008년 & 2009년 & 합계 \\
\hline 교육 & 0 & 0 & 367 & 68 & 321 & 94 & 0 & 0 & 0 & 0 & 850 \\
\hline 보건의료 & 4 & 0 & 0 & 0 & 5 & 0 & 7 & 0 & 0 & 0 & 16 \\
\hline 행정제도 & 245 & 54 & 326 & 80 & 24 & 32 & 108 & 0 & 0 & 47 & 916 \\
\hline 농어촌개발 & 0 & 0 & 0 & 5 & 6 & 8 & 7 & 9 & 0 & 0 & 35 \\
\hline
\end{tabular}




\begin{tabular}{c|r|r|r|r|r|r|r|r|r|r|r}
\hline 구분 & 2000년 & 2001년 & 2002년 & 2003년 & 2004년 & 2005년 & 2006년 & 2007년 & 2008년 & 2009년 & 합계 \\
\hline 정보통신 & 0 & 0 & 8 & 5 & 0 & 363 & 234 & 82 & 13 & 32 & 737 \\
\hline 산업에너지 & 0 & 0 & 0 & 0 & 0 & 0 & 0 & 0 & 0 & 11 & 11 \\
\hline 환경 및 기타 & 0 & 0 & 0 & 0 & 0 & 0 & 0 & 0 & 189 & 21 & 210 \\
\hline 긴급구호 & 0 & 0 & 0 & 0 & 0 & 0 & 0 & 46 & 0 & 0 & 46 \\
\hline 합계 & 249 & 54 & 701 & 158 & 356 & 497 & 356 & 137 & 202 & 111 & 2,821 \\
\hline
\end{tabular}

출처: $\mathrm{KOICA}$ 대외무상원조 통계 재구성

\section{3) 엘살바도르}

엘살바도르는 최근 몇 년간 한국 ODA가 급증하고 있는 국가이다. 2008년 3월 28일에는 KOICA 엘살바도르 사무소를 개설하고 협력국의 요청사항을 파악하면서 엘살바도르의 발전에 도움이 되는 프로젝트를 추진하고 있다. 이러한 노력으로 2010년 1월에는 한국과 엘살바도르간의 무상원조기본협 정에 서명하고 같은 해 8월 11일 공식적으로 발효되었다. ${ }^{15)}$ 협정은 기본틀 내에서 양자 간에 합의된 무상원조 프로그램 및 프로젝트 이행을 통해 엘살바도르 공화국의 경제 · 사회 발전 증진을 위하여 노력하는 것을 목적으로 한다. 이 협정을 통해 양국 간에 이루어지는 무상원조 형태에 대해 규정하고 있는데, 크게 7 개 항목으로 이루어진다. 첫째는 국내연수 프로그램에 엘살바도르 공화국 국민의 초 청, 둘째 한국의 경험, 지식 및 기술을 전수하고, 프로젝트 및 프로그램 추진할 한국 전문가 파견, 셋 째 엘살바도르의 경제, 사회 개발사업의 연구수행 및 공동 또는 합동 프로그램의 수행을 위한 한국 전문가 파견, 넷째 한국 해외봉사단의 엘살바도르 파견, 다섯째 엘살바도르에 장비, 기계류 및 물자 의 지원, 여섯째 원조사업 수행에 있어서 엘살바도르 정부의 협조, 일곱째 상호 간에 합의된 그 밖의 형태의 무상원조의 지원 등을 내용으로 한다. 이와 같이 협정을 통해 상호간의 신뢰를 확인하고 제도 적으로 지원하게 되었다는 점에서 의미하는 바가 크다. 이러한 협정과 제도적 지원에 따라 2011년 1월 해외봉사단이 최초로 파견되었다. ${ }^{16)}$

〈표 9〉엘살바도르 지원 규모

(단위: 만 달러)

\begin{tabular}{c|c|c|c|c|c|c|c|c|c|c|c}
\hline 연도 & 91 00년 & 2001년 & 2002년 & 2003년 & 2004년 & 2005년 & 2006년 & 2007년 & 2008년 & 2009년 & 계 \\
\hline 지원액 & 212 & 22 & 63 & 21 & 30 & 197 & 30 & 123 & 196 & 385 & 1,278 \\
\hline
\end{tabular}

출처: $\mathrm{KOICA}$ 통계 자료

엘살바도르는 태평양 연안을 따라 북서쪽에서 남동쪽으로 화산대가 이어져 화산 폭발이 자주 발생하

15) 관보, "한국과 엘살바도르간의 무상원조기본협정" 제17322호, $(2010.8,17)$ p.3.

16) 세계일보, "남미 엘살바도르에 한국 최초 해외봉사단 파견", (세계일보, 2011.01.16.) 
는 지역으로 자연재해가 빈번히 발생한다. 이 과정에서 농업용수와 식수 공급이 절대적으로 부족하다. 한국은 이런 문제를 해결하기 위해 농업용수와 식수 문제 해결을 위한 프로젝트에 많이 지원했다. 엘살 바도르인들은 교육 문제에 많은 관심을 보이고 있는데 한국의 교육을 벤치마킹하고자 하기 때문에 국 내초청연수에 특히 많이 참여하고 있다. 물자지원은 중미지역이 화산폭발, 허리케인 상륙, 홍수와 같 은 자연재해가 빈번히 발생하기 때문에 불규칙적으로 증가하는 사업형태이다. 이런 이유로 어떤 측면 에서 보면 중미의 $\mathrm{ODA}$ 의 상당 부분이 물자지원이었다. 다음으로 많은 지원은 초청연수인데, 내용을 보 면 대부분이 농작물 재배법과 관련된 연수이다. 이 분야는 엘살바도르에서 분명히 필요한 분야이지만 국내초청보다는 현지 전문가 파견을 확대하는 것이 바람직하다. 예를 들어 같은 작물이라고 하더라고 자연조건에 따라 성장 속도와 결실을 맺는 수준이 상당히 다르게 나타나기 때문이다. 중미와 한국과 완 전히 다른 지리적 자연조건을 지니고 있다는 것을 고려하면 지원 방법의 개선이 필요하다.

지금까지 추진된 지원 사업을 사업형태별로 보면 프로젝트가 11건이고, 물자지원이 24건, 긴급구 호 5 건이며 국내초청연수가 183 명으로 다른 국가들에 비해 상대적으로 많은 것이 특징이다. 대부분 의 프로젝트들은 1 년 이상인 경우가 많지만 지원 규모는 상대적으로 적다. 이는 엘살바도르의 국내 경제규모와도 무관하지 않다.

〈표 10〉엘살바도르 사업형태별/분야별 지원 현황

\begin{tabular}{|c|c|c|}
\hline 사업 형태 & 사업내용 (사업기간 / 지원규모) & 분야 \\
\hline \multirow{12}{*}{$\begin{array}{c}\text { 프로젝트 } \\
\text { (12건) }\end{array}$} & 엘살바도르 식수공급시설지원(1995-1996/31만 달러) & 보건 \\
\hline & 엘살바도르 농촌식수공급사업 (1997-1998/54만 달러) & 농림수산 \\
\hline & 엘살바도르 IT 교육센타 지원사업(2002-2003/40만 달러) & 교육 \\
\hline & 엘살바도르 중미기술연구소 현대화 2차사업(2004-2005/33만 달러) & 산업에너지 \\
\hline & 엘살바도르 소비자보호청 IT 시스템 구축사업(2005-2006/57만 달러) & 공공행정 \\
\hline & 엘살바도르 소야빵고시 초중등학교 시설개선사업(2007-2008/51만 달러) & 교육 \\
\hline & 전염병 검사 · 관리 역량강화사업(2007/77만 달러) & 보건 \\
\hline & 엘살바도르 교육분야 정보통신기술 지원사업(2007-2009/242만 달러) & 교육 \\
\hline & 엘살바도르 임산부요양소 건립사업(2008-2009/170만 달러) & 보건 \\
\hline & 엘살바도르 채소재배 생산성 향상(2008-2009/71만 달러) & 농림수산 \\
\hline & 엘살바도르 외교부 정보시스템 및 사이버교육센터 설립지원(2009-2010/34만 달러) & 공공행정 \\
\hline & 엘살바도르 치안 역량 강화를 위한 감시경계시스템 구축사업(2010-2011/200만 달러) & 공공정행 \\
\hline 물자지원 & 24건(258만 달러) & - \\
\hline 긴급구호 & 5건(48만 달러) & - \\
\hline 국내초청연수 & 183명(113만 달러) & - \\
\hline 전문가 & 3명(4만 달러) & - \\
\hline
\end{tabular}

출처: $\mathrm{KOICA}$ 통계 자료 
2009년 한국의 대 엘살바도르 ODA는 주로 보건과 정보통신 부분에 집중되어 있다. 보건 부분은 주로 임산부 및 출산과 관련된 부분인데 특히 산후조리원 개원에 많은 노력을 기울이고 있다. 엘살바 도르 정부 요청에 따른 것으로 모자보건 사업의 일환으로 추진되었다. 2009년 사업을 시작한 이후 2010년 10월까지 엘살바도르 전국의 8개 지역에 산후조리원을 개원하여 엘살바도르인들의 모자보건 에 도움을 주고 있다. 이 모자보건 사업에서 한국은 이미 경험을 가지고 있어서 엘살바도르에서도 좋 은 성과를 거두고 있다. 정보통신 분야는 한국이 중미지역에서 집중적으로 센터 설립과 교육을 확대 하고 있는 사업이다.

\section{〈표 11〉2000년 2009년 엘살바도르 사업분야별 현황}

(단위: 백만원)

\begin{tabular}{c|r|r|r|r|r|r|r|r|r|r|r}
\hline 구분 & 2000년 & 2001년 & 2002년 & 2003년 & 2004년 & 2005년 & 2006년 & 2007년 & 2008년 & 2009년 & 합계 \\
\hline 교육 & 46 & 0 & 0 & 0 & 0 & 0 & 0 & 178 & 353 & 0 & 577 \\
\hline 보건의료 & 15 & 67 & 69 & 0 & 0 & 0 & 0 & 715 & 29 & 2,144 & 3,039 \\
\hline 행정제도 & 40 & 33 & 294 & 116 & 66 & 1,216 & 107 & 47 & 40 & 190 & 2,149 \\
\hline 농어촌개발 & 6 & 21 & 0 & 5 & 0 & 26 & 5 & 0 & 60 & 892 & 1,015 \\
\hline 정보통신 & 8 & 25 & 402 & 118 & 282 & 543 & 138 & 82 & 1,659 & 1,561 & 4,818 \\
\hline 산업에너지 & 0 & 5 & 12 & 6 & 0 & 9 & 32 & 12 & 18 & 38 & 132 \\
\hline 환경 및 기타 & 3 & 7 & 4, & 0 & 0 & 13 & 0 & 10 & 8 & 15 & 60 \\
\hline 긴급구호 & 0 & 128 & 0 & 0 & 0 & 210 & 0 & 92 & 0 & 58 & 488 \\
\hline 합계 & 118 & 286 & 781 & 245 & 348 & 2,017 & 282 & 1,136 & 2,167 & 4,898 & 12,278 \\
\hline
\end{tabular}

출처: $\mathrm{KOICA}$ 대외무상원조 통계 재구성

한국정부는 엘살바도르와 무상원조기본협정을 체결한 이후 지원을 확대하고 있는데 2010년에는 프 로젝트 6건, 연구초청 8과정에 24 명 등을 계획하고 이 중에 대부분의 계획이 차질없이 추진되었다.

\section{4) 온두라스}

온두라스는 2007년 178만불이었던 것이 2008년과 2009년에는 각각 60만불과 23만불로 지원 규 모가 급격히 감소했다. 최근 과테말라의 노동임금이 상승하면서 많은 한국기업들이 저임금 시장인 온두라스 이동하고 있는 것을 고려한다면 공적원조를 확대할 필요가 있다. 정부차원에서 직접적으로 한국기업들을 지원하지는 못하지만 공적원조 확대와 PPP 확대를 통해 한국과 기업의 이미지 제고를 위해 적극적으로 활용할 필요가 있다. 특히 온두라스는 중미에서 가장 많은 자원을 보유하고 있을 뿐 만 아니라 인구면에서 과테말라 다음으로 많은 인구규모를 지니고 있어 시장으로써의 역할도 가능하 다. 이런 배경에도 불구하고 온두라스의 공적원조가 확대되지 않는 것은 정치적인 이유가 있다. 지난 
2009년 셀라야 대통령의 친위 쿠데타가 실패한 이후 한국정부가 공적원조 확대에 미온적인 이유가 더 설득력을 얻고 있다.

〈표 12〉온두라스 지원 규모

(단위: 만 달러)

\begin{tabular}{c|c|c|c|c|c|c|c|c|c|c|c}
\hline 연도 & 91-00년 & 2001년 & 2002년 & 2003년 & 2004년 & 2005년 & 2006년 & 2007년 & 2008년 & 2009년 & 계 \\
\hline 지원액 & 234 & 9 & 10 & 42 & 6 & 8 & 45 & 178 & 60 & 23 & 616 \\
\hline
\end{tabular}

출처: $\mathrm{KOICA}$ 통계 자료

온두라스에 2010년 진행 중인 프로젝트는 산업기술훈련원에 대한 지원 사업이다. 그 외에 국내초 청연수가 많은 부분을 차지하고 있어 192 명으로 전체지원이 기술협력 중심으로 이뤄지고 있음을 알 수 있다.

〈표 13〉온두라스 사업형태별/분야별 지원 현황

\begin{tabular}{l|l|c}
\hline \multirow{2}{*}{ 사업 형태 } & \multicolumn{1}{|c}{ 사업내용 (사업기간 / 지원규모) } & 분야 \\
\hline \multirow{3}{*}{ 프로젝트(4건) } & 온두라스 산업기술훈련원 지원사업(1997-2000/115만 달러) & 교육 \\
\cline { 2 - 4 } & 온두라스 CLIPER병원 증축 및 기자재지원(2002-2003/37만 달러) & 보건 \\
\cline { 2 - 4 } & 한-온 기술훈련원 2차 지원사업(2005-2007/94만 달러) & 교육 \\
\cline { 2 - 3 } & 온두라스 신생아사망률 감소 지원사업(2006-2008/63만 달러) & 보건 \\
\hline 물자지원 & 컴퓨터, 기자재 지원 등 15건(137만 달러) & - \\
\hline 긴급구호 & 4건(9만 달러) & - \\
\hline 국내초청연수 & 192명(147만 달러) & - \\
\hline 전문가 & 9 명(13만 달러) & - \\
\hline
\end{tabular}

출처: $\mathrm{KOICA}$ 통계 자료

온두라스의 경우에도 역시 보건의료 부분이 많은 부분을 차지한다. 다음으로는 교육과 행정제도 개선이 뒤를 잇고 있다. 그외 부분에 대한 지원은 매우 적은 것으로 나타났다. 전체적으로 온두라스 에 대한 공적원조가 많지 않은데 2009년에 셀라야 대통령이 축출되고 과두정부가 들어서는 정치적 위기를 겪었다. 이에 대해 국제사회가 대외원조 지원을 중단하는 것과 한국의 원조 감소는 같은 맥락 이다. 과도정부 수립이후 미국과 EU가 지원 중단을 선언했고 여기에 많은 국가들이 동조했다. 
〈표 14〉2000년 2009년 온두라스 사업분야별 현황

(단위: 백만원)

\begin{tabular}{c|r|r|r|r|r|r|r|r|r|r|r}
\hline 구분 & 2000년 & 2001년 & 2002년 & 2003년 & 2004년 & 2005년 & 2006년 & 2007년 & 2008년 & 2009년 & 합계 \\
\hline 교육 & 29 & 0 & 0 & 5 & 0 & 16 & 326 & 548 & 0 & 0 & 924 \\
\hline 보건의료 & 26 & 28 & 14 & 437 & 0 & 6 & 40 & 654 & 96 & 0 & 1,301 \\
\hline 행정제도 & 21 & 19 & 96 & 37 & 35 & 27 & 21 & 362 & 193 & 104 & 915 \\
\hline 농어촌개발 & 0 & 9 & 0 & 11 & 11 & 10 & 0 & 0 & 27 & 16 & 84 \\
\hline 정보통신 & 0 & 10 & 8 & 15 & 12 & 0 & 26 & 36 & 44 & 38 & 189 \\
\hline 산업에너지 & 0 & 0 & 5 & 0 & 11 & 20 & 0 & 0 & 261 & 133 & 430 \\
\hline 환경및기타 & 0 & 19 & 5 & 0 & 0 & 0 & 14 & 48 & 0 & 0 & 86 \\
\hline 긴급구호 & 0 & 25 & 0 & 0 & 0 & 0 & 0 & 0 & 38 & 0 & 63 \\
\hline 합계 & 76 & 110 & 128 & 505 & 69 & 79 & 427 & 1,648 & 659 & 291 & 3,992 \\
\hline
\end{tabular}

출처: $\mathrm{KOICA}$ 대외무상원조 통계 재구성

이와 같이 양자 원조와 무상원조를 중심으로 한국의 중미 ODA 현황을 살펴봤는데 공통적인 특성 은 ICT와 직업교육 분야에 대한 지원이 확대되었다. ICT 분야의 지원은 공여국인 한국의 장점에서 출발하고 있으며, 이에 대응하여 협력국들의 요구도 증가하고 있는 분야였다. 한국의 정보통신기술 이 현지의 교육프로그램에 정착되는 효과를 가져왔다. ICT분야와 연계하여 행정제도 개선에서도 한 국의 $\mathrm{ODA}$ 지원이 많이 진행되었다. 이런 부분에 대한 지원은 한국의 장점을 살린다는 측면에서 긍정 적이라 할 수 있다. 또한 한국 $\mathrm{ODA}$ 는 모자보건 분야에 대한 지원을 확대하고 있는데, 모자보건 분야 는 유엔의 새천년개발목표를 달성할 수 있는 분야로 많은 지원이 확대되어야 할 분야이다. 제한된 영 역에서 한국 $\mathrm{ODA}$ 는 성과를 내고 있었으나 지원 규모와 사업 영역이 협소하다는 단점을 지니고 있었 다.

한국의 대중미 $\mathrm{ODA}$ 는 지원 규모가 절대적으로 부족했다. 중미 국가들이 사회경제적 규모가 작기 때문에 지원 규모을 조금만 확대해도 협력국의 사회적 조건 변화를 유도할 수 있다는 측면에서 지원 규모의 확대를 고려해야 한다. 그리고 지원 기간은 중·장기 전략을 수립하여 지원할 필요가 있다. 앞에서 본 바와 같이 특정한 국가의 경우 약속한 지원이 실행되지 않는 사례도 있었고, 사업의 확대 해야 됨에도 재원부족으로 중단하는 사례들도 있었다. 이런 측면에서 지속적인 지원이 필요하다.

이런 문제들은 크게 두 가지 정책 방향을 조정함으로써 일부 개선될 수 있을 것으로 판단된다. 사 실 이 두가지 과제는 2장에서 살펴본 바와 같이 한국 ODA 전체가 개선해야 할 과제이기도 하다. 첫 번째 문제는 지원 형태와 관련된 것으로 대부분의 사업이 단기적인 지원과 성과를 고려한 프로젝트 형 사업이었다. 프로젝트 사업은 특정한 사업 영역에서는 빠른 성과를 가져오고 사업의 완결성은 높 지만 협력국 사회의 수요를 사업 단계에서부터 조율할 수 없다는 한계성을 지니고 있다. 한국의 개발 
경험을 전수할 수 있는 개발 프로그램 중심이 아닌 프로젝트 중심의 개발협력이라는 한계를 지니고 있었다. 두 번째는 이런 문제들에 개별국가들의 사회경제적 조건을 충분히 반영하고 한국 ODA의 '선 택과 집중'을 통해 수립한 국별협력전략의 수립이다. 현재까지 중점협력대상국가들을 중심으로 국별 협력전략이 수립되었지만 여전히 협력국의 사회경제 발전과 조응하기보다는 원조의 수월성과 효과성 이 먼저 고려되었다. 협력국 원조 수요와 공여국의 장점을 살린 원조 효과성이 사회 전반으로 확대될 수 있는 국별협력전략이 필요하다.

\section{IV. 한국 중미 ODA 지원의 과제}

\section{1. 프로그램형 접근법의 적용 확대}

한국의 대 중미 원조 현황을 분석한 결과에 따르면 한국은 중미지역에서 과테말라를 중점협력대상 국으로 선정하고, ICT 분야를 중심으로 프로젝트형 사업을 추진하고 있었다. 최근에는 남미지역에서 성공적으로 추진한 모자보건을 중심으로 한 보건의료 분야에 대한 지원을 확대하고 있었다. 그렇지 만 한국 $\mathrm{ODA}$ 는 규모면에서 다른 선진 공여국들과 비교했을 때 많은 차이가 있었다. 이런 한계점들을 극복하고 한국의 경험을 전수하면서 개도국의 발전을 지원할 수 있는 다양한 프로그램의 개발이 필 요하다. 특히 중미지역이 원거리임을 고려하여 한국의 ODA가 효과적으로 추진될 수 있는 제도적 환 경을 마련하는 것이 필요하다. 제도적인 차원의 문제는 협력국의 지원이 없으면 불가능하기 때문에 협력국의 원조 수요를 파악하고 개발계획 단계에서 사후 발전 과정에 이러는 전체적인 로드맵을 작 성하여 접근해야 한다. 때문에 단기 프로젝트보다는 장기적이고 협력국의 발전 프로그램에 포함되는 프로그램 원조로 전환할 필요가 있다.

프로그램형 접근법 $(\mathrm{PBA})$ 은 '협력국의 개발프로그램에 바탕을 둔 접근'이다. 따라서 협력국이 주인 의식과 책임정신을 가지고 개발 프로그램을 수립, 추진하는데 공여국이 이를 부수적으로 지원하는 것으로서, 협력국의 주인의식에 입각한 개발 프로그램과 이에 대한 공여국의 지원을 아우르는 유기 적인 관계 혹은 방식을 뜻하는 개념이다. ${ }^{17)}$ 이러한 프로그램형 원조는 원조효과성이 요구하는 조건 들을 충족시켜야 하기 때문에 원조의 효과성을 자연스럽게 높일 수 있다. 프로그램 원조는 몇 가지 측면에서 프로젝트 원조와 차별성을 지닌다. 첫째, 지원 결과 및 책임에서 프로젝트에 국한되지 않고 개발정책에 포함된다. 둘째, 자금용도 제한에서도 프로젝트는 사업 달성을 위한 세부적인 자금용도 제한이 있으나 프로그램에서는 자금용도를 제한하지만 정책의 달성이 목적이다. 셋째, 협력국 주인

17) 이현주, 『한국 ODA의 프로그램형 접근법(PBA) 도입방안』, KOICA, 2010), p.14., Sida,"How to Start Working with a Programme-Based Approach, (Sida, Department for Methodologies and Effectiveness, 2008), p.3. 
의식 및 책임분담은 프로젝트에 따라 상이하나 대부분 공여국의 관여가 많고, 프로그램에서는 협력 국 주인의식의 중요성을 강조하고 개발계획 단계에서의 공여국의 역할도 인정한다. 넷째, 공여국간 협력이라는 측면에서 프로젝트 원조는 제한적이나 프로그램 원조에서는 협력국의 리더십 하에서 공 여국간 지원절차를 조율할 수 있다. ${ }^{18)}$ 프로그램형 원조는 협력국의 개발 프로그램 추진 단계에서부 터 참여하여 ODA가 효율적으로 집행할 수 있도록 행정적인 지원뿐만 아니라 프로그램을 설계할 수 있어, 공여국의 장점과 협력국의 수요를 지원 결정 단계에서부터 최종적인 사업 종결시까지 관리할 수 있다. 따라서 프로그램형 원조가 확대되면 원조 효과성에 관한 파리선언 및 아크라 행동계획상 이 행지표 달성에도 도움이 된다.

현재 우리나라의 대외원조 시스템에서는 예산지원, 비구속성 원조 확대, 협력국 시스템 활용, 공 여국간 지원 절차 조율 등과 같은 제도개선이 필요하다. 프로그램형 원조에 대한 논의가 확대되고는 있으나 아직 구체적인 실행 계획은 없는 상태이다. 공여국의 제도개선과 더불어 정책 환경 및 지원분 야별 개발여건 등 협력국에 대한 정확한 정보를 확보해야 한다. ${ }^{19)}$ 또한 협력국의 개발 프로그램에 포함시키기 위해서는 국가 개발계획 검토, 정책과제 발굴 - 평가, 공여국간의 절차 조율 등이 이루어 져야 프로그램형 원조가 성과를 거둘 수 있다.

\section{2. 국별협력전략의 확대}

한국의 대중미 개발협력은 중미지역이 남미 지역에 비해 지리적·환경적·인구학적·경제적 특성 이 뚜렷함에도 불구하고 중미와 남미를 아우르는 중남미라는 지역에 포함되어 분류된다. 따라서 중 미지역의 특성에 맞는, 중미 국가들간의 경제발전 정도, 교육 수준, 정치 발전, 환경적 취약성 등의 차이를 고려한 개발협력 방향이 설정되지 못하고 있다. ${ }^{20)}$ 이런 상황에서 중미지역의 개별 국가의 특 성을 고려한 국별협력전략(Country Partnership Strategy)을 수립하고 있다고 하기 어렵다. 국별협 력전략은 개발 효과성 증대를 위한 국제사회의 공동노력의 일환으로 등장하여 1990 년대 후반부터 선 진원조기관과 주요 ODA 공여국을 중심으로 도입되었으며 국별지원전략(CAS: Country Assistance Strategy)이라는 용어를 거쳐 국별협력전략(CPS)란 이름으로 자리 잡았다.

우리나라도 2007년 7월 20일 '공적개발원조 중기전략(2008-2010)'을 채택했다. 같은 해 8월 7일 외교통상부가 '국별지원전략 작성지침'을 마련하여 2007년 12월 19개 무상원조 중점협력대상국 중 17 개 대상국의 국별지원전략을 수립하여 운영했다. ${ }^{21)}$ 아울러 2011년부터는 국별협력전략을 수립하 고 있다. 우리나라의 국별협력전략에 대한 평가는 크게 3 가지로 이루어지고 있다. 첫째, 제도적 준비

18) 경협조사자료, 『국제 ODA 동향』, (한국수출입은행, 2009), p.4.

19) 경협조사자료, 『국제 ODA 동향』, (한국수출입은행, 2009), p.12.

20) 김진오, 권기수, 고희채, 박미숙, 『한-중미 경제협력 확대 방안』(KIEP, 2010), p.204

21) 박병식, "ODA 국별지원전략 평가기준 관계분석에 관한 연구: CAS 평가보고서 내용 분석을 통해", "한국사회와 행정 연구』, 제21권 제3호,(2010.11), p. 332. 
도 측면을 살펴보면, 한국 공적개발원조(ODA) 체계에서 국별협력전략은 무상원조 부문과 유상원조 부문에서 각각 만들어지고 있다. 그러나 일부 국가를 제외하고는 일반에게 공개되지 않기 때문에 민 간 부분과의 연계나 시너지 효과가 크게 나타나지 않고 있다. ${ }^{22)}$ 둘째, 한국 국별협력전략의 내용적 충실도를 세계은행 및 영국 등 국별지원전략을 잘 활용하고 있는 것으로 평가되는 공여기관(국)과 비 교하여 살펴보면, 아직까지 필수적으로 포함되어야 하는 여러 요소가 부족하고, 논리적 명확성이 떨 어진다. 셋째, 국별협력전략이 한국 개발원조 프로세스에 원활하게 반영되고 있지 않다. 전략을 수립 하기 위한 원조정책대화 단계에서는 포괄적 정책전략에 근거한 협의보다는, 협력국 정부의 개별 사 업 신청서에 기초하여 사업별 확정을 위한 대화가 주를 이루고 있다. ${ }^{23)}$

이런 제도적인 문제를 안고 있는 국별협력전략이 개발 효과성으로 이어지기 위해서는 한홍렬·이 호생이 지적하는 것처럼 선택과 집중, 개발효과성과 관련된 제반원칙 등 국별협력전략에 대한 국제 적인 합의를 반영해야 한다. 그리고 한국형 $\mathrm{ODA}$ 를 고려한 차별화 전략이 필요하다. ${ }^{24)}$ 현재 운영 중 인 국별협력전략의 성과에 대한 엄격한 평가를 바탕으로 국별협력전략을 수정해야 할 것이며, 우리 와 무상원조기본협정을 체결한 엘살바도르와 같은 국가들에 대한 국별협력전략을 수립하여 운영해야 한다.

\section{V. 결 론}

한국은 지난 2009년 11월 OECD/DAC의 24번째 회원국이 되었다. ODA 수원국에서 공여국으로 전 환된 유일한 국가이다. 1950년 한국전쟁의 폐허 속에서 60년 만에 명실상부한 선진국의 지위를 획득 한 것이라 할 수 있다. 한국의 빠른 성장은 재론의 여지없이 한국민의 노력이 있었기 때문에 가능했 다. 이와 더불어 선진국들의 해외원조도 중요한 역할을 했다는 것을 부정할 수 없다. 이런 과거 때문 에 한국의 $\mathrm{OECD} / \mathrm{DAC}$ 가입은 선진 공여국에게는 새로운 동반자의 등장이라는 측면에서 큰 관심을 끌고 있고, 협력국들은 자신들도 한국과 같은 길을 걸을 수 있을 것이라는 기대감을 갖게 했다. 한국 의 성공은 개도국에게는 경제발전에 자신감을 심어주는 주요한 사례로 여겨져 한국의 공적원조는 개 발도상국가에 재정적인 원조뿐만 아니라 정신적 원조를 하고 있는 셈이다.

그 동안 과테말라를 거점으로 중미지역에 대한 원조협력을 확대해 온 한국은 강점인 IT분야에서는 많은 성과를 거둔 것으로 평가된다. 한국 중미 ODA 지원의 특성은 ICT와 직업교육 분야에 대한 지 원이 확대되었다. ICT 분야의 지원은 공여국인 한국의 장점에서 출발하고 있으며, 이에 대응하여 협 력국들의 요구도 증가하고 있는 분야였다. 한국의 정보통신기술이 현지의 교육프로그램에 정착되는

22) 한홍렬, 이호생, "한국의 ODA 국별지원전략(CAS) 현황과 개선 방향”, (국제경제연구소, Working Paper, 2010), p.21.

23) 정유아, “한국 공적개발원조(ODA)의 '국가협력전략(CAS)' 활용 현황과 과제” "ODA Watch』, 28호(2009)

24) 한홍렬, 이호생, "한국의 ODA 국별지원전략(CAS) 현황과 개선 방향", (국제경제연구소, Working Paper, 2010), p.23. 
효과를 가져왔다. ICT분야와 연계하여 행정제도 개선에서도 한국의 ODA 지원이 많이 진행되었다. 이런 부분에 대한 지원은 한국의 장점을 살린다는 측면에서 긍정적이라 할 수 있다. 또한 한국 ODA 는 모자보건 분야에 대한 지원을 확대하고 있는데, 모자보건 분야는 유엔(UN)의 새천년개발목표 (MDGs)를 달성할 수 있는 분야로 국제적인 빈곤퇴치 요구에 부응하는 분야였다. 한국의 개발경험을 전수할 수 있는 개발 프로그램 중심이 아닌 프로젝트 중심의 개발협력이었다는 것은 향후의 도전과 제로 지적할 수 있다.

프로젝트 단위의 지원과 한국의 개발경험 전수를 위해서는 사업 형태와 국별협력전략을 구체화시 킬 필요가 있다. 특히, 최근 국제 원조 사회에서는 협력국의 개발 프로그램에 기반한 지원형태를 확 대하고 있는데, 한국은 프로그램형 원조가 매우 낮은 수준에서 이루어지고 있다. 사실 중미와 같은 중소득국가들은 국가발전을 위한 전략을 수립하고 계획 시행하고자 하는 의지와 행정체계를 갖추고 있어서 더욱 절실하게 프로그램형 원조를 원하고 있다. 중기전략으로 추진한 국별협력전략이 마무리 되는 단계에 이르렀기 때문에 국별협력전략을 새롭게 계획하고 엘살바도르와 같이 무상원조기본협정 을 체결한 국가에 대해서도 중점협력대상국 선정과 함께 국별협력전략을 마련할 필요가 있다.

사실 가장 큰 과제 중 하나는 한국의 대 중미 원조 규모를 확대하는 것이다. 이 문제는 DAC 가입 으로 정부차원에서 확대를 계획하는 문제이기 때문에 일정 정도 해소될 수 있을 것으로 기대된다. 증 액된 재원을 어떤 국가 혹은 어떤 분야에 집중할 것인가라는 '선택과 집중'의 문제가 중요한 사안으 로 등장했다. '선택과 집중' 의 결정이 집행 담당자, 현지 관리자, 협력국의 당국자, 국내 민간단체의 전문가 등의 심도 깊은 논의를 통해 이루어질 수 있기를 바란다. 그리고 이 과정이 한국 $\mathrm{ODA}$ 지원 체제의 개선과 맞물러 있다는 측면에서 특정 지역에 대한 지원의 문제만이 아닐 것이다. 중미지역에 대한 제도개선과 함께 지원이 확대될 수 있기를 기대한다. 


\section{참고문헌}

\section{1. 국내문헌}

경협조사자료, 『국제 ODA 동향』, (한국수출입은행, 2009).

고경민, 김순임, 홍진혁, “공적개발원조(ODA)와 국인: 한국 ODA정책의 발전을 위한 함의”, 『한 국과 국제정치』, 제 26 권 제 3 호, (경남대학교, 극동문제연구소, 2010).

고경민, 이희진, “한국 공적개발원조의 문제점과 혁신 방향: 적극적 평화론적 관점에서” 국가 전략』, 제14권 4호(2008).

관계부처 합동, 「국제개발협력 선진화 방안」, 관계부처 합동, (2010).

관보, “한국과 엘살바도르간의 무상원조기본협정” 제17322호, (2010. 8.17).

권율, 정지선, “국제사회의 파리선언 이행 현황과 시사점”, KIEP, 『오늘의 세계경제』, (대외경 제정책연구원, 2008) 참조.

김경덕, 김정승, $\ulcorner\mathrm{OECD} / \mathrm{DAC}$ 가입에 따른 개발도상국 농업기술지원 전략」, (한국농촌경제연구원, 2010).

김영철, 구경모, 김유경, 박종욱, 「한·중미 개발협력방안 연구」, (대외경제정책연구원, 2010). 김준연, “한-중남미 IT 서비스 분야 협력 및 현지 시장 진출 방안”, 한중남미협회, ${ }^{\circledR}$ 제 14 차 한 중남미 비즈니스 포럼』, (한중남미협회, 2010).

김진오, 권기수, 고희채, 박미숙, 『한-중미 경제협력 확대 방안』(KIEP, 2010).

박병식, “ODA 국별지원전략 평가기준 관계분석에 관한 연구: CAS 평가보고서 내용 분석을 통해”,

『한국사회와 행정연구』, 제21권 제3호,(2010.11), p. 332.

외교통상부, 『국제개발협력기본법』, (외교통상부, 2010.07)

이계우, 박지훈(2007), “한국의 공적개발원도 20 년의 평가”, 『한국개발연구』, 제 29 권 제 2 호(통 권 제100호).

이현주, 『한국의 대 중남미 무상원조방안 연구』, (KOICA연구자료 정책연구, 2008).

『한국 ODA의 프로그램형 접근법(PBA) 도입방안』, )KOICA 연구자료, 정책연구, 2010). 정유아, “한국 공적개발원조(ODA)의 '국가지원전략(CAS)' 활용 현황과 과제” ${ }^{\circledR O D A ~ W a t c h 』, ~ 28 ㅎ ㅗ ~}$ (2009).

주인중, 김상진, “과테말라 기술교육훈련원 건립 사업 사후평가", 「국제개발협력」, 2008년 2호 (한국국제협력단, 2008). 
참여연대, 『한국 구속성 원조의 현황과 문제점』, (참여연대 국제연대위원회 정책보고서, 2010). 최원식, “한국의 대중미 개발협력 사례와 협력확대 방안” 한중남미협회, 『제 14 차 한 · 중남미 비 즈니스 포럼』, (한중남미협회, 2010).

한홍렬, 이호생, “한국의 $\mathrm{ODA}$ 국별지원전략(CAS) 현황과 개선 방향”, (국제경제연구소, Working Paper, 2010).

세계일보, “남미 엘살바도르에 한국 최초 해외봉사단 파견”, (세계일보, 2011.01.16.)

중앙일보, “이상득, ‘자원외교' 특사로 중남미 방문”, (중앙일보, 2010.01.18.)

\section{2. 국외문헌}

Sida, "How to Start Working with a Programme-Based Approach, (Sida, Department for Methodologies and Effectiveness, 2008)

ODA Watch, (23호) "아크라 행동계획(AAA) 채택의 의의와 과제", http://www.odawatch.net/?mid $=$ articlesth\&page $=20 \&$ document_srl $=2048(2011.05 .12)$.

OECD/DAC, "Development aid reaches an historic high in 2010", http://webnet.oecd.org/ oda2010/(2011.05.12).

"USA Profile” www.development-finance.org/en/component/.../634-usa-24-09-2009.html(2011.5.30) 